\title{
Coordinate measuring arms - different methods of points collection
}

\author{
Współrzędnościowe ramiona \\ pomiarowe - różne metody \\ zbierania punktów
}

DOI: https://doi.org/10.17814/mechanik.2017.12.200

\author{
MICHAŁ RAK \\ EUGENIUSZ RATAJCZYK*
}

This paper deals with different methods of points collection using coordinate measuring arm. The research is divided into two parts. The first one is about measuring an aluminum cube with different geometric features with the use of hard probe and laser scanner. For the analysis some features and some resulting parameters were applied, like angle between two planes. As the reference, data from CMM measurements is used due to obtain higher level of accuracy of device. In the second part, a Teflon cube was used for the measurement. As this is a softer material than aluminum, measuring force gives significant impact on the results. To verify this, hard and triggering head was used.

KEYWORDS: measuring arm, points collection, contact measurements, non-contact measurements

Niniejszy artykuł dotyczy różnych metod zbierania punktów za pomocą współrzędnościowych ramion pomiarowych. Badania są podzielone na dwie części. Pierwsza odnosi się do pomiarów aluminiowej kostki z elementami o różnej geometrii z użyciem końcówki stykowej i skanera laserowego. Do analizy zastosowano niektóre elementy i parametry wynikowe, jak kąt pomiędzy dwiema płaszczyznami. Jako odniesienie zastosowano wyniki pomiarów z CMM z uwagi na większą dokładność tego urządzenia. W drugiej części do pomiarów zastosowano kostkę z teflonu. Ponieważ jest to materiał bardziej miękki niż aluminium; siła pomiarowa znacząco wpłynie na wyniki. Aby to sprawdzić, uźyto głowicy sztywnej i przełączajacej.

SŁOWA KLUCZOWE: ramię pomiarowe, zbieranie punktów, pomiar kontaktowy, pomiar bezkontaktowy

Coordinate measuring techniques are subject to rapid developments due to the automation of measurements, the integration with CAD/CAM systems and the use of computer analysis and archiving the results [1]. The first and still most common device in coordinate metrology is the coordinate measuring machine (CMM). The accuracy of a CMM depends on the type of construction and the measuring head. It is in the range from tens of microns to tenths of a micron.

\footnotetext{
* Dr inż. Michał Rak - Warsaw University of Technology, Faculty of Mechatronics, Polytechnique Montréal, Department of Mechanical Engineering; prof. dr hab. inż. Eugeniusz Ratajczyk (erat33@interia.pl) - University of Ecology and Management
} 
In recent years, coordinate measuring arms have gained more attention [2-4]. Measuring arms are characterized by a lower accuracy as compared to CMMs, but they are fully portable. They can be used directly in the production and a field and they are able to measure inside large objects.

In general, during the part inspection two technologies can be used: contact and non-contact [5, 6].

During the contact measurements, high accuracy points from a surface are acquired by physical contact with the surface.

During the non-contact measurements, data from the whole object is gathered in a short time. Unfortunately, in non-contact methods, there is a possibility of larger uncertainty of points, that reduces the benefit from higher density of points [5].

Measuring arm can be equipped with a laser scanner for performing the non-contact measurement, but also with contact probes. Two types of contact probes can be used: hard probe, for which an operator decides if a probe tip has a contact with measured surface and trigger probe, for which the contact is detected automatically.

In this paper, research shows a comparison of measurements of special cubes. The measurements are performed by graduate students of Prof. Ratajczyk.

There is a following paper organization. First, the measuring equipment is described. Then, procedures of measurements with different types of measuring heads are presented. Next section includes results of the measurements and their discussion. Finally, a conclusion of the research is presented.

\section{Experiment}

- Measuring equipment. Comparative studies were performed on coordinate measuring arm by Metris-Nikon [7] model MCA II. This is a 6-axis arm, and using a scanner, it becomes a 7-axis arm. The spatial accuracy is $40 \mu \mathrm{m}$ according to the ASME standard [8]. Depending on the test performed, the arm was fitted with different probes. To total accuracy of the measuring, the system was determined as geometric sum of the arm's and the probe's accuracy.

- Contact vs. non-contact measurements. First part of the research is performed using hard probe and laser scanner. As a part of test, an aluminum cube was selected. It is presented on fig. 1.

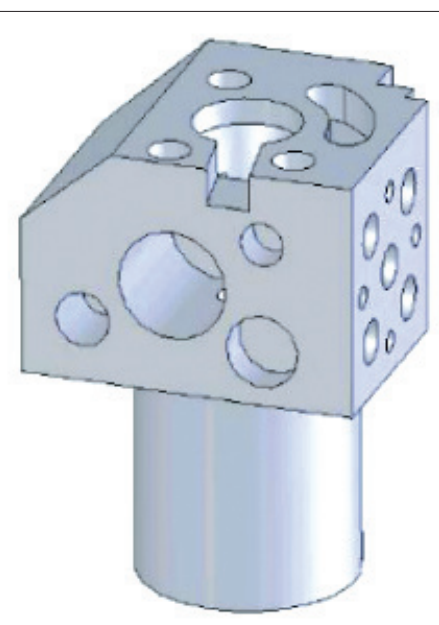

Fig. 1. Aluminum cube
The material has good optical properties and no additional preparation of the surface is required. Several characteristics are selected for the analysis. Following features can be directly measured as one: two circles $C 1$ and $C 2$ with diameters of $30 \mathrm{~mm}$. Moreover, two indirect dimensions are chosen. They are determined based on plane measurements: angle $A 1$ with the nominal value of $40^{\circ}$, and distance $D$ between two planes with the nominal value of $78 \mathrm{~mm}$. Series of measurements are performed to determine selected characteristics using two types of measuring head.

- Hard vs. trigger probe. In the second part, the influence of measuring force is analyzed. A Teflon cube, which is rather a soft material, is measured using hard and trigger probes. This probe has constant triggering force and the contact is detected at the same pressure through the measurement. The CAD model of the Teflon cube with selected characteristics is presented on fig. 2 .

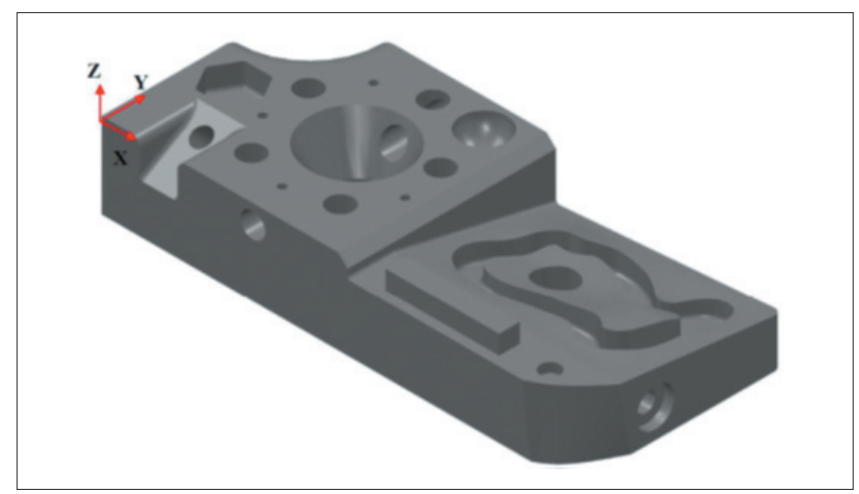

Fig. 2. Teflon cube

Several characteristics are selected for the analysis. Following features can be directly measured: two circles C3 and C4 with diameters of $13.002 \mathrm{~mm}$ and a sphere $\mathrm{S} 1$ with a diameter of $24 \mathrm{~mm}$. One indirect dimension is chosen; it is determined based on plane measurements: angle $A 2$ with the nominal value of $90^{\circ}$. Series of measurements are performed to determine selected characteristics using two types of measuring head.

Measurements in both parts of the research are performed in the air-conditioned laboratory to eliminate the effect of external factors on results. The cubes are fixed steadily to the marble table to avoid movement during measurements.

\section{Results and discussion}

Measurements are performed on the coordinate measuring arm and compared with the reference data obtained from the CMM.

In the first part of research, contact measurements are compared with non-contact one. Measurements are performed by Jan Guzy - graduate student of Prof. Ratajczyk. Results obtained from contact measurements are presented in table I.

Distance between two planes was calculated from the following formula:

$$
D=\frac{d 12+d 21}{2}
$$

where: $d 12$ - distance between center of gravity of the $1^{\text {st }}$ plane and the $2^{\text {nd }}$ plane, $d 21$ - distance between center of gravity of the $2^{\text {nd }}$ plane and the $1^{\text {st }}$ plane. 
It can be seen from table I that results are close to relevant reference values. What can be noted is the influence of the measuring force. The measured values are higher for measurements of internal dimensions like circles and the angle; moreover, they are lower for external dimension like the distance between two planes. It is caused by microdeflection of the probe's stylus during the measurement.

TABLE I. Results for contact measurements

\begin{tabular}{|l|c|c|c|c|}
\hline CMM (reference) & $\varnothing \mathrm{C} 1, \mathrm{~mm}$ & $\varnothing \mathrm{C} 2, \mathrm{~mm}$ & $D, \mathrm{~mm}$ & $A 1,^{\circ}$ \\
\hline Mean value & 30.036 & 29.007 & 78.099 & 40.002 \\
\hline Standard deviation & 0.00503 & 0.00630 & 0.01539 & $\begin{array}{c}0.02106 \\
\left(1^{\prime} 16^{\prime \prime}\right)\end{array}$ \\
\hline Range of results & 0.017 & 0.023 & 0.059 & $\begin{array}{c}0.076 \\
\left(4^{\prime} 33^{\prime \prime}\right)\end{array}$ \\
\hline
\end{tabular}

TABLE II. Results for non-contact measurements

\begin{tabular}{|l|c|c|c|c|}
\hline & $\varnothing C 1, \mathrm{~mm}$ & $\varnothing \mathrm{C} 2, \mathrm{~mm}$ & $D, \mathrm{~mm}$ & $A 1,^{\circ}$ \\
\hline CMM (reference) & 30.004 & 29.007 & 78.099 & 40.002 \\
\hline Mean value & 30.091 & 30.029 & 77.955 & 39.934 \\
\hline Standard deviation & 0.05397 & 0.04381 & 0.03613 & $\begin{array}{c}0.09047 \\
\left(5^{\prime} 26^{\prime \prime}\right)\end{array}$ \\
\hline Range of results & 0.183 & 0.154 & 0.138 & $\begin{array}{c}0.296 \\
\left(17^{\prime} 46^{\prime \prime}\right)\end{array}$ \\
\hline
\end{tabular}

It is noticeable that higher standard deviation of the results is obtained for indirect measurements. This is the effect of errors propagation. Uncertainties of each measurement propagate to the combination of variables in the function.

Second type of measurements is performed using laser scanner working on the principle of triangulation. Table II presents results for non-contact measurements.

Here, the difference between measurement and reference data is much higher and ranges from $87 \mu \mathrm{m}$ to 144 $\mu \mathrm{m}$ for the linear dimensions. For angular dimension, it is around 4'. It proves that non-contact measurements are characterized by lower precision comparing to the contact methods.

Results for circles are higher than the reference and results for the distance and the angle are lower. As an aluminum cube is used, it cannot be caused by absorption or scattering of the measured surface. It is rather caused by noise, which is much higher for parts with many edges. The noise is also visible in standard deviations of results. For some characteristics, it is ten times higher than for contact measurements.

Contact and non-contact methods are compared based on selected characteristics. In this paper, two types of comparison are presented. Firstly, there is a comparison of mean values and secondly, it is a comparison of standard deviations.

In the comparison of means, it has been set the confidence interval as $95 \%$, then we make two hypotheses. The zero hypothesis says that the means are equal and the alternative one that they are not. Researchers determine the $P$-value parameter and based on it, thy state whether the differences are statistically significant or not.

Similar situation is for comparison of standard deviations. It has been set confidence interval as $95 \%$ making two hypotheses. The zero hypothesis says that standard deviations are equal and the alternative that they are not. There are determination of the $P$-value of the test and based on its evaluation of significance of differences.

For all of analyzed characteristics, the differences in means and standard deviations for two types of measure- ments are statistically significant. It is worth noting that this statement is true with a $95 \%$ confidence interval.

In the second part of the research, two contact methods have been analyzed, but using different probes: hard and trigger. Also the test part was chosen to be susceptible to measuring force. Measurements presented in this part were performed by Karol M. Golasiński - graduate student of Prof. Ratajczyk. Results for contact measurements with hard probe are presented in table III.

TABLE III. Results for contact measurements with hard probe

\begin{tabular}{|l|c|c|c|c|}
\hline & $\varnothing \mathrm{C} 3, \mathrm{~mm}$ & $\varnothing \mathrm{C} 4, \mathrm{~mm}$ & $\varnothing \mathrm{S} 1, \mathrm{~mm}$ & $\mathrm{~A} 2,^{\circ}$ \\
\hline CMM (reference) & 13.005 & 13.002 & 24.001 & 89.998 \\
\hline Mean value & 13.055 & 13.056 & 23.948 & 89.884 \\
\hline Standard deviation & 0.016 & 0.014 & 0.055 & $\begin{array}{c}0.027 \\
\left(1^{\prime} 37^{\prime \prime}\right)\end{array}$ \\
\hline Range of results & 0.047 & 0.053 & 0.221 & $\begin{array}{c}0.094 \\
\left(5^{\prime} 38^{\prime \prime}\right)\end{array}$ \\
\hline
\end{tabular}

Comparing table I with table III, it is noticeable that for the cube made of much softer material, the difference between measurement and the reference is at least one order of magnitude higher. It is caused by deflection of the mesurand. For the circles, the measured diameter is 50 $\mu \mathrm{m}$, which is higher than the reference, which is a lot as for contact measurement.

Next, it is performed measurement of the same characteristics, maintaining the same external conditions, using trigger probe. The results are presented in table IV.

TABLE IV. Results for contact measurements with trigger probe

\begin{tabular}{|l|c|c|c|c|}
\hline & $\varnothing \mathrm{C} 3, \mathrm{~mm}$ & $\varnothing 4, \mathrm{~mm}$ & $\varnothing S 1, \mathrm{~mm}$ & $A 2,{ }^{\circ}$ \\
\hline CMM (reference) & 13.005 & 13.002 & 24.001 & 89.998 \\
\hline Mean value & 13.055 & 13.056 & 23.948 & 89.884 \\
\hline Standard deviation & 0.016 & 0.014 & 0.055 & $\begin{array}{c}0.027 \\
\left(1^{\prime} 37^{\prime \prime}\right)\end{array}$ \\
\hline Range of results & 0.047 & 0.053 & 0.221 & $\begin{array}{c}0.094 \\
\left(5^{\prime} 38^{\prime \prime}\right)\end{array}$ \\
\hline
\end{tabular}

Willing to compare the mean values for chosen characteristic for two probes, the differences between measured and reference data, which were treated as true values, were calculated. They are presented in table $\mathrm{V}$.

TABLE V. Comparison of mean values from two probes with reference values

\begin{tabular}{|l|c|c|}
\hline & $\begin{array}{c}\text { Hard probe measurement - } \\
\text { reference value }\end{array}$ & $\begin{array}{c}\text { Trigger probe measurement } \\
\text { - reference value }\end{array}$ \\
\hline$\varnothing C 3, \mathrm{~mm}$ & 0.050 & 0.004 \\
\hline$\varnothing C 4, \mathrm{~mm}$ & 0.054 & 0.007 \\
\hline$\varnothing S 1, \mathrm{~mm}$ & -0.053 & -0.006 \\
\hline$A 2,{ }^{\circ}$ & -0.114 & -0.078 \\
$\left(6^{\prime} 50^{\prime \prime}\right)$ & $\left(4^{\prime} 40^{\prime \prime}\right)$ \\
\hline
\end{tabular}

It is visible from table $\mathrm{V}$ that measurements performed using the trigger probe are much more precise than using the hard probe. For manual measuring devices like the arm, the influence of the operator is significant. Various measuring pressure is unpredictable in the results, which is particularly evidence for soft materials.

Similarly as for previous research, statistical analysis of obtained results is performed. It is used the comparison of means and comparison of standard deviations. Confidence interval was set at $95 \%$.

Significant differences appear only for comparison of means. It is caused by the fact that results from trigger probe are much closer to the true value (reference) than for hard probe. This is the consequence of deflection of 
the soft material caused by measuring force. It is much higher when hard probe is used.

For comparison of standard deviations, the statistical differences turned out to be insignificant. It is justified by the fact that the experienced operator is able to maintain similar value of measuring force through the measurement. This value is too high as for selected material, but it is approximately constant.

The obtained results show that depending on the properties of the inspected part, the measuring head should be selected with high attention. When the part with many features is measured, contact measurements are recommended. Non-contact methods are an attractive solution for big freeform surfaces, because inspection is performed in a short time. Also accuracy requirements for freeform surfaces are not so restrictive.

In case of soft materials, attention is paid on measuring force and if it is possible to decrease it, for example, by using trigger probes.

\section{Conclusions}

In this paper, different methods of points' collection with the use of a coordinate measuring arm were considered.

Research is divided into two parts. In the first one, aluminum cube is measured in contact and non-contact ways. For the contact measurement, a hard probe and for non-contact measurement, a laser scanner working on the principle of triangulation is used. The selected cube has good properties for both measurements. It is hard enough not to be deflected as the effect of measuring force and the surface has good optical properties, thus the laser is not scattered.

In the second part of research, it is aimed at examining the effect of measuring force. For this purpose, a Teflon cube is chosen, which is quite soft material. Measurements were performed in contact way using two types of probe: hard and trigger. In trigger probe, the measuring force is constant (for the TP20 probe, it is $0.08 \mathrm{~N}$ in $X Y$ and $0.75 \mathrm{~N}$ in $Z$ direction), while in hard probe, it depends on the operator and his experience.

In the first part of research, for contact method, it is noticed that all results are close to relevant reference values. The measured values comparing to the reference are higher for measurements of internal dimensions like circles and the angle, and lower for external dimension like the distance between two planes. It is caused by micro-deflection of the probe's stylus during the measurement.

It is noticeable that higher standard deviation of the results is obtained for indirect measurements, which is the effect of error propagation.

In turn, for non-contact measurements, the difference between the measurement and the reference data is much higher, which proves the lower precision of noncontact measurements.

Contact and non-contact methods were compared based on selected characteristics. We used comparison of means and comparison of standard deviations. In both, the confidence intervals were $95 \%$.

There are two hypotheses. The zero hypothesis says that the means or standard deviations are equal and the alternative one that they are not. We determine the $P$-value parameter and based on it, we state whether the differences are statistically significant or not.

The statistical analysis for the selected characteristics showed that the differences in means and standard devia- tions for two types of measurements are statistically significant. This shows how different are results from contact and non-contact methods.

In the second part of the research, two contact methods are analyzed but using different probes: hard and trigger.

Also the test part was chosen to be susceptible to measuring force.

It is noticeable that for contact measurement with the hard probe made on the softer cube, the difference between measurement and the reference is at least one order of magnitude higher. It is caused by deflection of the mesurand.

After performing the measurements with the use of trigger probe, results are much more precise than with the use of hard probe. It is typical for manual measuring devices like the arm, and the influence of the operator is significant.

Similarly as for previous research, statistical analysis of obtained results is performed. Comparison of means and comparison of standard deviations are used.

After statistical analysis, we noticed that significant differences appear only for comparison of means. These parameters are significantly different for both probes, which is the consequence of deflection of the soft material more visible for the hard probe.

Other situation appears with the comparison of standard deviations. In this case, the statistical differences are insignificant. Experienced operator is able to maintain similar value of measuring force through the measurement, hence dispersion of results is relatively low. The value of measuring force was too high as for selected material, but it was approximately constant.

The performed research, in both parts, showed that depending on the properties of inspected part, like softness or optical properties, the measuring head should be selected carefully. For the part with many features, contact measurements are recommended. They give high accuracy and when the part is rather small, the measurement is not tedious. Non-contact methods are an attractive solution for large freeform surfaces, because inspection is performed in a short time and probably requirements for the accuracy of freeform surfaces are lower than for precisely manufactured features.

In case of soft materials, attention is paid on measuring force and if it is possible to decrease it, for example, by using trigger probes.

It is also worth noticing that the measurements were performed in laboratory conditions. Measuring arms due to their construction can work in the direct vicinity of production line. It seems to be interesting to perform research and similar tests in this environment. It might be that the differences would not be statistically different.

\section{REFERENCES}

1. Ratajczyk E, Woźniak A. "Współrzędnościowe systemy pomiarowe”. Warszawa: Oficyna Wydawnicza Politechniki Warszawskiej, 2016.

2. Ratajczyk E. „Ramiona pomiarowe - budowa, parametry techniczne, zastosowania”. Mechanik. 12 (2008): pp. 1051-1054.

3. Ratajczyk E. „Ramiona pomiarowe - pomiary skaningowe i specjalne, pomiary w rozszerzonym zakresie, oprogramowania". Mechanik. 1 (2009): pp. 38-42.

4. Ratajczyk E. „Porównanie testów dokładności współrzędnościowych ramion pomiarowych". Mechanik. 8-9 (2010): pp. 588-594.

5. Martinez S. et al. "Analysis of laser scanning and strategies for dimensional and geometrical control". International Journal of Advanced Manufacturing Technology. 46 (2010): pp. 621-629.

6. Jamshidi J., Owen G.W., Mileham A.R. "A new data fusion method for scanned models". Journal of Computing and Information Science in Engineering. 6, 4 (2006): pp. 340-348.

7. www.nikonmetrology.com, www.smart-solutions.p

8. ASME B89.4.22-2004 "Methods for Performance Evaluation of Articulated Arm Coordinate Measuring Machines". 2004

9. www.renishaw.com 